\title{
The Oxygen Reduction Reaction on Nb-doped Titanium Dioxide Single Crystal Electrodes
}

\section{Natsumi KAMEDA, Masashi NAKAMURA, and Nagahiro HOSHI*}

Department of Applied Chemistry and Biotechnology, Graduate School of Engineering, Chiba University, 1-33 Yayoi-cho, Inage-ku, Chiba 263-8522, Japan

*Corresponding author: hoshi@faculty.chuiba-u.jp

\section{ABSTRACT}

Structural effects on the oxygen reduction reaction (ORR) have been studied on the low index planes of rutile $\mathrm{TiO}_{2}$ doped with $\mathrm{Nb}(0.05-$ $1 \mathrm{wt} \%$ ) in $0.1 \mathrm{~mol} \mathrm{~L}^{-1} \mathrm{HClO}_{4}$. The order of the ORR activity at $0.20 \mathrm{~V}\left(\mathrm{vs}\right.$. RHE) is $\mathrm{TiO}_{2}(100)<\mathrm{TiO}_{2}(111)<\mathrm{TiO} 2(110)$, and the activity increases with increasing $\mathrm{Nb}$ concentration. The activity of $\mathrm{TiO}_{2}(110)$ is 5.6 times as high as that of $\mathrm{TiO}_{2}(100)$ at $\mathrm{Nb}$ concentration 1 wt\%. The order of the ORR activity does not correlate with the amount of oxygen vacancy defects that are known as the active sites of the ORR of TiO 2 nanoparticles. The ORR activity of $1 \mathrm{wt} \% \mathrm{Nb}$-doped $\mathrm{TiO}_{2}(100)$ modified with melamine is 2.1 times higher than that of the unmodified one. The activity of $1 \mathrm{wt} \% \mathrm{Nb}$-doped $\mathrm{TiO}_{2}(110)$ modified with melamine is the highest in the low index planes of $\mathrm{TiO}_{2}$. Modification by tetra- $n-$ hexylammonium cation ( $\mathrm{THA}^{+}$) affects the ORR activity slightly.

(c) The Author(s) 2020. Published by ECSJ. This is an open access article distributed under the terms of the Creative Commons Attribution 4.0 License (CC BY, http://creativecommons.org/licenses/by/4.0/), which permits unrestricted reuse of the work in any medium provided the original work is properly cited. [DOI: 10.5796/electrochemistry.20-00105].

Keywords : The Oxygen Reduction Reaction, Nb-doped Titanium Dioxide Single Crystal Electrodes, Melamine, THA ${ }^{+}$

\section{Introduction}

Polymer electrolyte fuel cell (PEFC) is a clean energy conversion system because water is the only reaction product. However, the oxygen reduction reaction (ORR), which is a reaction of the air electrode of a fuel cell, has high overvoltage and slow reaction rate; large amount of $\mathrm{Pt}$ is used as catalysts of fuel cells at present. Reduction of Pt loading is necessary for expanding practical use of fuel cells, because the number of national resources of $\mathrm{Pt}$ is limited and the cost of $\mathrm{Pt}$ is high.

The current operating temperature of PEFC is from 80 to $90^{\circ} \mathrm{C}$. Higher operating temperature is required for PEFC to increase the efficiencies of power generation and heat exhaust. The nextgeneration PEFC targets the operation above $100^{\circ} \mathrm{C}$. Pt is not durable at the operation above $100^{\circ} \mathrm{C}$. We must find materials that have high durability and high activity for the ORR above $100^{\circ} \mathrm{C}$. Hamazaki et al. reported that the electrode using $\mathrm{Ti}_{4} \mathrm{O}_{7}$ is superior to the conventional electrode using carbon in durability and stability. ${ }^{1}$ Groenenboom et al. revealed that the overvoltage of the ORR on $\mathrm{Nb}$-doped $\mathrm{TiO}_{2}$ is lower than that of undoped $\mathrm{TiO}_{2}$ and the durability is as high as that of $\mathrm{TiO}_{2}{ }^{2}$ Yamamoto et al. predicted that the onset potential of the ORR of $\mathrm{TiO}_{2}$ doped with $\mathrm{Pd}$ or Rh equals to the equilibrium potential of the ORR. ${ }^{3}$ These results suggest that $\mathrm{TiO}_{2}$ electrodes have great potential of new cathode catalysts of fuel cells in the next generation. Many papers reported the ORR on $\mathrm{Pt}$ nanoparticles supported on $\mathrm{TiO}_{2}$ particles. ${ }^{4,5}$ However, there have been few reports on the ORR activity of $\mathrm{Nb}$-doped $\mathrm{TiO}_{2}$ without $\mathrm{Pt}$ nanoparticles. ${ }^{2,6}$

In this study, we have adopted the following three methods to improve the ORR activity of $\mathrm{Nb}$-doped $\mathrm{TiO}_{2}$ : (1) control of the surface in atomic level using single crystal electrodes, (2) modification of the surface with hydrophobic species, and (3) improvement of the conductivity by changing $\mathrm{Nb}$ concentration. An electrochemical reaction depends on a surface structure of the electrode $;^{7-10}$ study on the ORR activity using single crystal electrodes is effective for the elucidation of the active sites of the catalytic activity. Marković et al. reported that the ORR activity increases as $\operatorname{Pt}(100)<\operatorname{Pt}(111)<\operatorname{Pt}(110){ }^{11}$ However, structural effects on the ORR have not been studied on single crystal electrodes of $\mathrm{Nb}$-doped $\mathrm{TiO}_{2}$ except the report of Ota et al. ${ }^{12} \mathrm{We}$ have evaluated the ORR activity using $\mathrm{Nb}$-doped rutile $\mathrm{TiO}_{2}(100)$, $\mathrm{TiO}_{2}(110)$, and $\mathrm{TiO}_{2}(111)$ single crystal electrodes of which surfaces are regulated in atomic level. Previous study uses the double layer charge to estimate the relative ORR activity, ${ }^{12}$ whereas we use real surface area of $\mathrm{TiO}_{2}$ single crystal electrode to obtain the absolute value of the ORR activity. Figure S1(a) shows the hard sphere models of $\mathrm{TiO}_{2}$ single crystal surfaces examined.

Jinnouchi et al. predicted that the change of the adsorbed water structure destabilizes Pt oxides (blocking species of the ORR) to increase the ORR activity on stepped surfaces of $\mathrm{Pt} .{ }^{13}$ Hydrophobic organic species can also change the water structure, increasing the ORR activity. Asahi et al. and Miyabayashi et al. successfully increase the ORR activity of Pt nanoparticles by the modification with melamine and alkyl amines, respectively. ${ }^{14,15}$ Alkyl amines, melamine and tetra- $n$-hexylammonium cation $\left(\mathrm{THA}^{+}\right)$also enhance the ORR activity of Pt single crystal electrodes. ${ }^{16-18}$ Especially, melamine and $\mathrm{THA}^{+}$increase the activity of the stepped surfaces of $\mathrm{Pt}$ as well as $\mathrm{Pt}(111)$. Thus we have adopted melamine and $\mathrm{THA}^{+}$as modification species of $\mathrm{Nb}$-doped $\mathrm{TiO}_{2}$ single crystal electrodes. There has been no study on the effects of hydrophobic species on the ORR of $\mathrm{TiO}_{2}$. The structures of melamine and $\mathrm{THA}^{+}$ are shown in Fig. S1(b).

$\mathrm{TiO}_{2}$ is a semiconductor; it has almost no electrical conductivity without doping. $\mathrm{Nb}$ doping improves the electrical conductivity markedly. We have measured the ORR of $\mathrm{TiO}_{2}$ single crystal electrodes with the following three weight percentage of $\mathrm{Nb}$ : $0.05 \mathrm{wt} \%, 0.5 \mathrm{wt} \%$, and $1 \mathrm{wt} \%$.

In this communication, we have studied the ORR on Nb-doped $\mathrm{TiO}_{2}$ single crystal electrodes with and without hydrophobic organic species in $0.1 \mathrm{M} \mathrm{HClO}_{4}$. Previous studies show that the oxygen vacancy defects are the active sites of the ORR of $\mathrm{TiO}_{2}$ nanoparticles. ${ }^{19,20}$ Thus we have also estimated the amount of oxygen vacancy defects on $\mathrm{TiO}_{2}$ single crystal electrodes using Xray photoelectron spectroscopy (XPS) to elucidate whether the change of the activity is due to the surface structure or the amount of oxygen vacancy defects. 
(a)

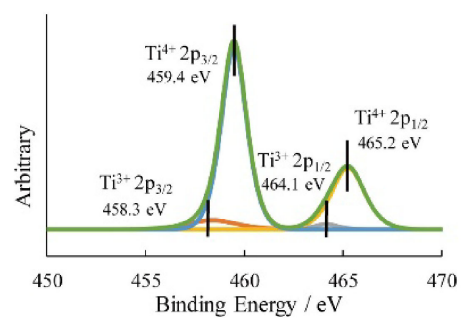

(b)

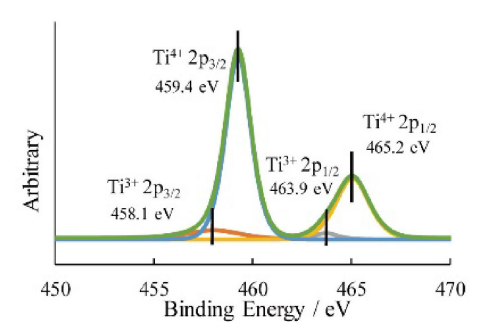

(c)

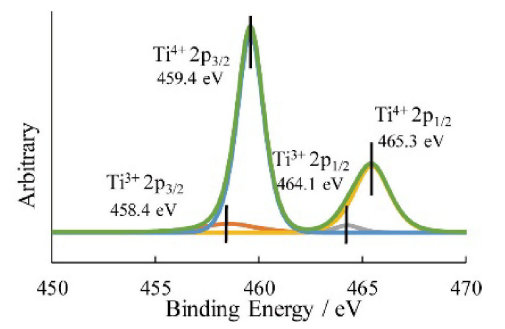

Figure 1. Ti $2 \mathrm{p}$ XPS spectra of $1 \mathrm{wt} \% \mathrm{Nb}$-doped $\mathrm{TiO}_{2}$ single crystals after the chemical polishing and the annealing. (a) $\mathrm{TiO}{ }_{2}(100)$, (b) $\mathrm{TiO}_{2}(110)$, (c) $\mathrm{TiO}_{2}(111)$.

\section{Experimental}

Perchloric acid (ultrapure) and hydrofluoric acid (ultrapure) were purchased from Kanto Chemical Co. Inc. Melamine and $\mathrm{THA}^{+}$were obtained from Wako Pure Chemical Industries, Ltd. and SigmaAldrich, respectively. All the electrolytic solutions were prepared with ultrapure water produced using Milli-Q Advantage A10 (Millipore). Rutile type $\mathrm{TiO}_{2}$ single crystal plates $(10 \mathrm{~mm} \times 10$ $\mathrm{mm} \times 0.50 \mathrm{~mm}$ ) doped with $\mathrm{Nb}$ were purchased from Shinkosha Ltd.

Surface treatment method by Imanishi et al. was used to prepare atomically flat $\mathrm{TiO}_{2}$ surfaces. ${ }^{21}$ Chemical polishing was done by immersing $\mathrm{TiO}_{2}$ single crystals in $30 \mathrm{wt} \%$ hydrofluoric acid aqueous solution for 6 hours, and then the $\mathrm{TiO}_{2}$ single crystals were annealed at $600{ }^{\circ} \mathrm{C}$ for 1.5 hours in air. The flatness of the surface was estimated using atomic force microscope (AFM) (Multi Mode 8, Bruker) in air.

The amount of oxygen vacancy defects was estimated using XPS (JPS-9030, JEOL Ltd.) in ultra-high vacuum $\left(2.0 \times 10^{-8} \mathrm{~Pa}\right)$. XPS spectra were obtained using an $\mathrm{MgK} \alpha$ line $(1253.6 \mathrm{eV})$ as the $\mathrm{X}$-ray source.

Modification with hydrophobic species was done as follows. Aqueous solutions of melamine $\left(0.7 \mathrm{mmol} \mathrm{L}^{-1}(\mathrm{mM})\right)$ and $\mathrm{THA}^{+}$ $(0.01 \mathrm{mM})$ were prepared. Atomically flat $\mathrm{TiO}_{2}$ single crystals were immersed in the solution for 10 minutes. Excess hydrophobic species was removed by rinsing the electrode three times with ultrapure water.

We measured voltammograms using electrochemical analyzer (ALS 701D, BAS) and rotating ring disc electrode (RRDE-3, BAS). Linear sweep voltammogram (LSV) was measured from 0.05 to $1.0 \mathrm{~V}$ (vs. RHE) at scanning rate of $0.010 \mathrm{~V} \mathrm{~s}^{-1}$ in $0.1 \mathrm{M} \mathrm{HClO}_{4}$ saturated with $\mathrm{O}_{2}$. The rotation speed was $1600 \mathrm{rpm}$. IR drop was corrected in all the voltammograms. The ORR activity was evaluated using cathodic current density at $0.20 \mathrm{~V}$ (vs. RHE). We use a geometric area of the electrode as a real surface area because the surface of the single crystal electrode is atomically flat. A Pt plate was adhered to the back of $\mathrm{TiO}_{2}$ single crystal plate using In/ Ga alloy to improve the electrical conductivity with RRDE- $3 .{ }^{21}$ The resistance values of the $\mathrm{Nb}$-doped $\mathrm{TiO}_{2}$ single crystal electrodes were 12-18 $\Omega$. The $\mathrm{TiO}_{2}$ single crystal electrode with Pt plate was set to homemade Teflon holder, and connected to RRDE-3. Only well-defined surface of $\mathrm{TiO}_{2}$ electrode has contact with the electrolytic solution using this holder.

\section{Results and Discussion}

Figure S2 shows AFM images of single crystal surfaces of $1 \mathrm{wt} \%$ $\mathrm{Nb}$-doped $\mathrm{TiO}_{2}$ electrodes after the surface treatment. The surfaces are composed of wide terraces and monoatomic steps. Roughness of the terrace is within $0.2 \mathrm{~nm}$. Ionic radii of $\mathrm{Ti}^{4+}$ and $\mathrm{O}^{2-}$ are $0.075 \mathrm{~nm}$ and $0.14 \mathrm{~nm}$, respectively; the roughness of the terrace is within one atom. Thus we have judged that the surfaces were smooth in atomic level.
Figure 1 shows XPS spectra of $\mathrm{Nb}$ doped $\mathrm{TiO}_{2}$ single crystal electrodes. The peaks around $458 \mathrm{eV}$ and $459 \mathrm{eV}$ are assigned to $2 \mathrm{p}_{3 / 2}$ orbitals of $\mathrm{Ti}^{3+}$ and $\mathrm{Ti}^{4+}$, respectively. The peaks around $464 \mathrm{eV}$ and $465 \mathrm{eV}$ are due to $2 \mathrm{p}_{1 / 2}$ orbitals of $\mathrm{Ti}^{3+}$ and $\mathrm{Ti}^{4+}$, respectively. Larger $458 \mathrm{eV}$ peak indicates that more oxygen vacancy defects exist on the surface. ${ }^{22}$ Table S1 shows the ratio of the peak area around $458 \mathrm{eV}$ to the total peak area. There is no significant difference in the amount of oxygen vacancy defects as shown in Table S1. The amount of oxygen vacancy defects does not correlate with that of the ORR activity as shown later.

Figures $2(\mathrm{a}-\mathrm{c})$ show the voltammograms of $\mathrm{Nb}$-doped $\mathrm{TiO}_{2}$ single crystal electrodes in $0.1 \mathrm{M} \mathrm{HClO}_{4}$ saturated with Ar. When the $\mathrm{Nb}$ concentration increases, the conductive carrier density in the electrode also increases, resulting in higher current density. Redox peaks appear around $0.3 \mathrm{~V}$ (vs. RHE) on all surfaces at $\mathrm{Nb}$ concentration 0.05 and $1 \mathrm{wt} \%$. The origin of these redox peaks is not known at present. No remarkable structural effect is found in the voltammograms. Voltammograms of $1 \mathrm{wt} \% \mathrm{Nb}$-doped $\mathrm{TiO}_{2}$ modified with melamine and $\mathrm{THA}^{+}$were almost identical with those of the unmodified ones.

Figure $\mathrm{S} 3$ shows $\mathrm{LSV}$ of the low index planes of $\mathrm{Nb}$-doped $\mathrm{TiO}_{2}$ in $0.1 \mathrm{M} \mathrm{HClO}_{4}$ saturated with $\mathrm{O}_{2}$. Cathodic currents depend on the surface structure significantly. The ORR activity is improved with increasing $\mathrm{Nb}$ concentration. The activity increases as $\mathrm{TiO}_{2}(100)<$ $\mathrm{TiO}_{2}(111)<\mathrm{TiO}_{2}(110)$ regardless of the $\mathrm{Nb}$ concentrations. Figure 2(d) illustrates the ORR activity at $0.20 \mathrm{~V}$ (vs. RHE). The ORR activity of $\mathrm{TiO}_{2}(110)(1 \mathrm{wt} \% \mathrm{Nb})$ is 5.6 times as high as that of $\mathrm{TiO}_{2}(100)(1 \mathrm{wt} \% \mathrm{Nb})$, whereas the amount of oxygen vacancy defects does not depend on the surface structure significantly (Table S1). These results clearly show that surface structures rather than oxygen vacancy defects govern the activity for the ORR on well-defined $\mathrm{TiO}_{2}$ single crystal electrodes.

We estimated the onset potential of the ORR $\left(E_{\text {onset }}\right)$ using the potential at which cathodic current density reaches $0.1 \mu \mathrm{A} \mathrm{cm}^{-2}$ in $\mathrm{O}_{2}$ saturated solution. Table S2 summarizes the values of $E_{\text {onset }}$. $E_{\text {onset }}$ shifts to higher potential with the increase of $\mathrm{Nb}$ concentration. $E_{\text {onset }}$ gets higher as $\mathrm{TiO}_{2}(100)<\mathrm{TiO}_{2}(111)<\mathrm{TiO}_{2}(110)$ at any $\mathrm{Nb}$ concentration, giving the same activity series as that estimated using cathodic current density at $0.20 \mathrm{~V}$ (vs. RHE).

The highest activity of $\mathrm{TiO}_{2}(110)$ may be related to the surface energy. Previous studies show that the rate-determining steps of the ORR on $\mathrm{TiO}_{2}$ surface are $\mathrm{OH}$ formation and $\mathrm{H}_{2} \mathrm{O}$ desorption. ${ }^{23,24}$ If $\mathrm{OH}$ is easily generated or $\mathrm{H}_{2} \mathrm{O}$ is desorbed quickly, the ORR will become active. The surface energy of $\mathrm{TiO}_{2}(110)$ is the smallest in the low index planes, giving the weakest bonding force between the surface and molecules. ${ }^{25}$ Therefore, $\mathrm{H}_{2} \mathrm{O}$ molecules on $\mathrm{TiO}_{2}(110)$ are most easily desorbed in the low index planes, giving the highest ORR activity.

LSVs are also measured on $1 \% \mathrm{Nb}$-doped $\mathrm{TiO}_{2}$ single crystal electrodes modified with hydrophobic species. Figure $\mathrm{S} 4$ shows LSV of the Nb-doped $\mathrm{TiO}_{2}$ electrodes in $0.1 \mathrm{M} \mathrm{HClO}_{4}$ saturated with 
(a)
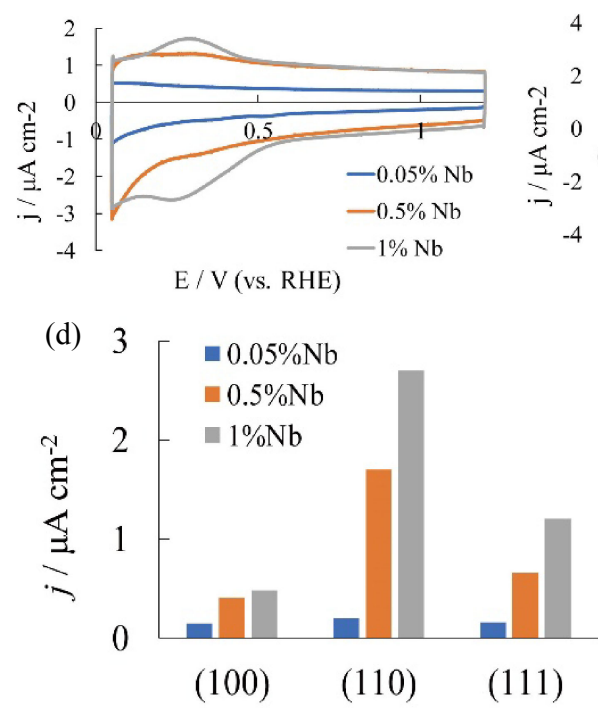

(b)

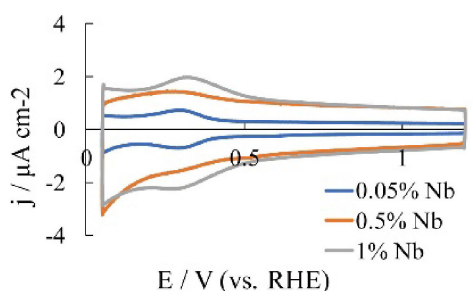

(e) 4 (c)

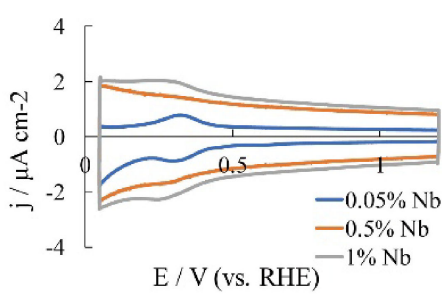

E / V (vs. RHE)

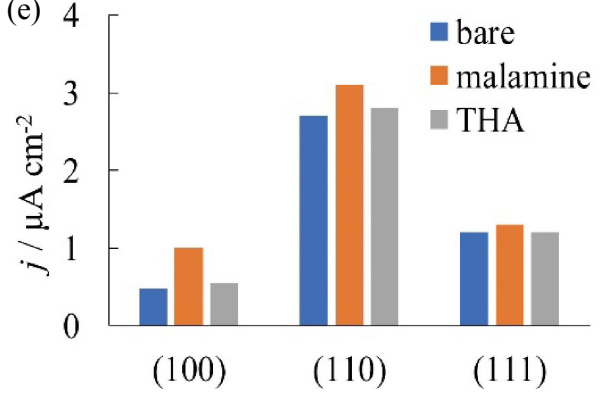

Figure 2. Voltammograms of $\mathrm{Nb}$-doped $\mathrm{TiO}_{2}$ single crystals in $0.1 \mathrm{M} \mathrm{HClO}_{4}$ saturated with $\mathrm{Ar}$ : (a) $\mathrm{TiO}_{2}(100)$, (b) $\mathrm{TiO}_{2}(110)$, (c) TiO 2 (111). (d) Structural and Nb-doping effects on the ORR activity in $0.1 \mathrm{M} \mathrm{HClO}_{4}$ at $0.20 \mathrm{~V}$ (vs. RHE). (e) The ORR activity of $1 \mathrm{wt} \% \mathrm{Nb}$-doped TiO 2 modified with hydrophobic species.

$\mathrm{O}_{2}$. The order of $E_{\text {onset }}$ (Table S2) is equal to that of the ORR activity at $0.20 \mathrm{~V}$ (vs. RHE) of bare surfaces, but the order was changed by the modification with the hydrophobic species. Melamine/ $\mathrm{TiO}_{2}(111)$ has the highest $E_{\text {onset }}(0.41 \mathrm{~V}$ (vs. RHE)) in the surfaces examined. Figure 2(e) shows the ORR activity at $0.20 \mathrm{~V}$ (vs. RHE) on bare and modified $1 \% \mathrm{Nb}$-doped $\mathrm{TiO}_{2}$ electrodes. Melamine increases the ORR activity of all the $\mathrm{TiO}_{2}$ single crystal electrodes. Melamine $/ \mathrm{TiO}_{2}(110)$ has the highest ORR activity $\left(2.7 \mu \mathrm{Acm}^{-2}\right)$ in the surfaces examined. Melamine $/ \mathrm{TiO}_{2}(100)$ gives the highest activity improvement ratio: the ORR activity of melamine/ $\mathrm{TiO}_{2}(100)$ is 2.1 times higher than that of bare $\mathrm{TiO}_{2}(100)$. Enhancement ratio of the ORR by $\mathrm{THA}^{+}$is smaller than that of melamine. The order of the activity of the ORR after the modification is identical with that of bare surfaces: $\mathrm{TiO}_{2}(100)<$ $\mathrm{TiO}_{2}(111)<\mathrm{TiO}_{2}(110)$.

At present, we do not have the solid evidence of the mechanism of the structural effects and the enhancement of the activity by hydrophobic organic species on $\mathrm{TiO}_{2}$ single crystal electrodes. Studies on the structural effects on the carrier density and the adsorbed species are now on progress using impedance measurement and vibrational spectroscopy in our laboratory.

\section{Conclusion}

The order of the ORR activity on Nb-doped single crystal electrodes of $\mathrm{TiO}_{2}$ is $\mathrm{TiO}_{2}(100)<\mathrm{TiO}_{2}(111)<\mathrm{TiO}_{2}(110)$ at $0.20 \mathrm{~V}$ (vs. RHE) regardless of the $\mathrm{Nb}$ concentration, and the activity is improved by increasing the $\mathrm{Nb}$ concentration. The ORR activity of $1 \mathrm{wt} \% \mathrm{Nb}$-doped $\mathrm{TiO}_{2}(110)$ is 5.6 times higher than that of $1 \mathrm{wt} \%$ $\mathrm{Nb}$-doped $\mathrm{TiO}_{2}(100)$. Melamine modification increases the ORR activity of all the $\mathrm{TiO}_{2}$ single crystals. The ORR activity of melamine modified $\mathrm{TiO}_{2}(100)$ is 2.1 times as high as that of unmodified one. Melamine modified $\mathrm{TiO}_{2}(110)$ gives the highest activity for the ORR. Enhancement ratio of the ORR by $\mathrm{THA}^{+}$is much smaller than that by melamine.

\section{Supporting Information}

The Supporting Information is available on the website at DOI: https://doi.org/10.5796/electrochemistry.20-00105.

\section{References}

1. M. Hamazaki, A. Ishihara, Y. Kohno, K. Matsuzawa, S. Mitsushima, and K. Ota, Electrochemistry, 83, 817 (2015).

2. M. C. Groenenboom, R. M. Anderson, D. J. Horton, Y. Basdogan, D. F. Roeper, S. A. Policastro, and J. A. Keith, J. Phys. Chem. C, 121, 16825 (2017).

3. Y. Yamamoto, S. Kasamatsu, and O. Sugino, J. Phys. Chem. C, 123, 19486 (2019).

4. P. S. M. Kumar, V. K. Ponnusamy, K. R. Deepthi, G. Kumar, A. Pugazhendhi, H. Abe, S. Thiripuranthagan, U. Pal, and S. K. Krishnan, J. Mater. Chem. A, 6, 23435 (2018).

5. K. J. Noh, I. Nam, and J. W. Han, Appl. Surf. Sci., 521, 146330 (2020).

6. A. Ishihara, M. Arao, M. Matsumoto, T. Tokai, T. Nagai, Y. Kuroda, K. Matsuzawa, H. Imai, S. Mitsushima, and K. Ota, Int. J. Hydrogen Energy, 45, 5438 (2020).

7. R. Adzić, Modern Aspects of Electrochemistry vol. 21 (Eds. R. E. White, J. O'M. Bockris, and B. E. Conway), Plenum Press, New York, p. 163 (1990).

8. C. Lamy and J. M. Leger, J. Chim. Phys., 88, 1649 (1991).

9. N. M. Marković and P. N. Ross, Jr., Surf. Sci. Rep., 45, 117 (2002).

10. S. Ye, T. Kondo, N. Hoshi, J. Inukai, S. Yoshimoto, M. Osawa, and K. Itaya, Electrochemistry, 77, 2 (2009).

11. N. M. Marković, R. R. Adžić, B. D. Cahan, and E. B. Yeager, J. Electroanal. Chem., 377, 249 (1994).

12. K. Ota, J. Hirata, T. Nagai, M. Arao, M. Matsumoto, Y. Kuroda, K. Matsuzawa, H. Imai, S. Mitsushima, and A. Ishihara, ECS Trans., 86(13), 549 (2018).

13. R. Jinnouchi, K. Kodama, and Y. Morimoto, J. Electroanal. Chem., 716, 31 (2014).

14. M. Asahi, S. Yamazaki, N. Taguchi, and T. Ioroi, J. Electrochem. Soc., 166, F498 (2019).

15. K. Miyabayashi, H. Nishihara, and M. Miyake, Langmuir, 30, 2936 (2014).

16. K. Saikawa, M. Nakamura, and N. Hoshi, Electrochem. Commun., 87, 5 (2018).

17. N. Wada, M. Nakamura, and N. Hoshi, Electrocatalysis, 11, 275 (2020)

18. T. Kumeda, H. Tajiri, O. Sakata, N. Hoshi, and M. Nakamura, Nat. Commun., 9, 4378 (2018).

19. K. Ota, T. Nagai, Y. Tamura, M. Arao, M. Matsumoto, K. Matsuzawa, H. Imai, T. W. Napporn, S. Mitsushima, and A. Ishihara, ECS Trans., 80(8), 717 (2017).

20. K. Ota, Y. Ohgi, K. Nam, K. Matsuzawa, S. Mitsushima, and A. Ishihara, J. Power Sources, 196, 5256 (2011).

21. A. Imanishi, H. Suzuki, N. Ohashi, T. Ohta, and Y. Nakato, Inorg. Chim. Acta, 361, 778 (2008).

22. E. Farfan-Arribas and R. J. Madix, Surf. Sci., 544, 241 (2003).

23. J. Matthiesen, S. Wendt, J. Ø. Hansen, G. K. H. Madsen, E. Lira, P. Galliker, E. K. Vestergaard, R. Schaub, E. Lægsgaard, B. Hammer, and F. Besenbacher, ACS Nano, 3, 517 (2009).

24. D. N. Pei, L. Gong, A. Y. Zhang, X. Zhang, J. J. Chen, Y. Mu, and H. Q. Yu, Nat. Commun., 6, 8696 (2015).

25. Y. Yamamoto, K. Nakajima, T. Ohsawa, Y. Matsumoto, and H. Koinuma, Jpn. J. Appl. Phys., 44, L511 (2005). 